\title{
EVALUATION OF ONLINE LEARNING IN NATURAL SCIENCE FOR JUNIOR HIGH SCHOOL
}

\author{
Nurrana Fitria Luthfi ${ }^{1}$, Syukrul Hamdi ${ }^{2 *}$ \\ ${ }^{1}$ Department of Educational Research and Evaluation, Universitas Negeri Yogyakarta \\ Jl. Colombo No. 1, Karangmalang, Depok, Sleman, Yogyakarta 55281, Indonesia \\ ${ }^{2}$ Department of Mathematics Education, Universitas Negeri Yogyakarta \\ Jl. Colombo No. 1, Karangmalang, Depok, Sleman, Yogyakarta 55281, Indonesia \\ *Corresponding Author. E-mail: syukrulhamdi@uny.ac.id
}

\begin{abstract}
This research aims to evaluate the online learning system in natural science subject for the junior high school level in Yogyakarta. This research uses CIPP (Context, Input, Process, Product). The research subjects are two school principals, five natural science teachers, and 267 grade VII, VIII, and IX students in State Junior High School (sekolah menengah pertama negeri or SMPN) 9 Yogyakarta and Nurul Ummah Islamic Junior High School (Madrasah Tsanawiyah or MTs), Kotagede, Yogyakarta. Data were collected through questionnaires and interview guidelines validated through the process of expert judgment to prove the construct validity using Exploratory Factor Analysis (EFA). The instrument's reliability was analyzed using Alpha Cronbach, while the results were analyzed using the qualitative descriptive method. According to the context aspect, the results of this research are in the form of online school program objectives to meet the needs of flexibility, ideal operational technology tools, and the professionalism of Natural Science teachers in practicum activities considered in the fairly good category. According to the input context, the results are in the form of an online system supported by the internet access facility and the scheduling, procedure, and capabilities of Natural Science teachers, considered in the good category. According to the process aspect, the results are in the form of online learning, considered in the good category. Meanwhile, according to the product aspect, the results are in the form of quality achievement on learning outcomes and the support of the online learning system implementation, considered in the good category.
\end{abstract}

Keywords: online learning system, natural science, junior high school, evaluation, CIPP

How to cite: Luthfi, N., \& Hamdi, S. (2020). Evaluation of online learning in Natural Science for junior high school. Jurnal Penelitian dan Evaluasi Pendidikan, 24(2), 218-227. doi:https://doi.org/10.21831/pep.v24i2.35015

\section{INTRODUCTION}

The government, as the main stakeholder (Ulmunir, 2018), determines alternative options related to the planning for the feasibility of investing in education. According to Hasbullah (2015), to produce humans who are intellectually excellent, morally stable, competent in mastering science and technology, and have ideals of commitment to various social roles, it is necessary to have a democratic, decentralized, and diversity-oriented education system. To achieve those goals, equity and the accessibility of educational opportunities accompanied by policies regulating quality management in the corridor of educating the nation are needed.

The atmosphere of the COVID-19 pandemic has brought vital changes to various sectors. The development of the virus has spread very quickly around the world. Indonesia is also 
stated to be in the national emergency. The fatality rate due to Corona virus has continued to increase since it was first announced that there were people who were declared positive for the COVID-19 in early March 2020. New policies that have been set in the education sector changed the learning process. Students who initially always come to class or campus, are forced to conduct the learning from home (Sari et al., 2018). Along with panic buying due to the transmission of the virus and the process of finding solutions in (Islam et al., 2020) controlling infection, vaccine discovery, and treatment, the readiness of the government in providing alternative educational policies in educating the nation is important and needed to help educators and students so that teaching and learning activities can be carried out through remote learning. Trial and error that occurred during the virus pandemic have become a dilemma in the world of education. However, online learning is needed and it plays a very important role in improving the quality of education in Indonesia, as we know that modern humans use internet access and technological innovations in education every day to gain knowledge (Wirawan, 2016) to meet the general requirements in accordance with the respective scientific fields, one of which is Natural Science.

The principle of Natural Science learning in (Khamidah et al., 2019), refers to the regulation of the Minister of Education and Culture No. 22 of 2016 which concerns the standard of primary and secondary education processes, and the recommendation in the learning process to utilize information and communication technology to increase the efficiency and effectiveness of learning. According to Wisudawati (2013), teachers need to optimize the strategies created to develop skills through the potential of students through practicum activities.

According to Khamidah et al. (2019), demanding deep learning to build and create knowledge independently (constructivism), collaborating with other learners in building knowledge and solving problems together (social constructivism), forming an inclusive community of learners (community of learners), utilizing a web page (website) that can be accessed via the internet, computer-based learning, virtual classes, or digital classes, as well as interactivity, independence, accessibility, and enrichment in order to meet the expectations of the curriculum, urgently need the right learning strategy. Therefore, it needs synchronization between theoretical and practical learning, especially at the junior high school level.

This research uses the CIPP evaluation model developed by Stufflebeam. According to Sari et al. (2018), the uniqueness of this model lies in the decision-making tools. Context evaluation relates to the things that will be planned which include the basic needs required to develop a program. Input evaluation analyzes existing sources and determines which sources can be used so as to achieve the objectives set. Process aspect, monitors, documents, and assesses program activities. Meanwhile, product aspect assesses and provides an interpretation of the project's achievements, whether it has arrived at the end of the project cycle or in the middle of the cycle because this evaluation deals with decisions regarding whether this activity should be continued, modified, stopped, or repeated. Referring to OECD (2016, p. 32), education requires an efficient system, especially professional educators to uphold the entity of knowledge during the learning process.

\section{RESEARCH METHOD}

This research was evaluation research to collect data, present information, and describe the real situation in the field regarding the online learning system in the Natural Science subject. The research data were processed and compared with the success criteria. On this occasion, the evaluation was focused on five aspects, namely: context (context), preparation (input), process (process), outcome (product), and impact (impact). According to Siswadi et al. (2019), this evaluation model framework is more comprehensive to guide planning, implementation, and assessment, especially in learning programs. This evaluation research was conducted from April to May 2020. The research was carried out in several locations as listed in Table 1. 
Table 1. Research Location

\begin{tabular}{ccc}
\hline No. & Province & School Name \\
\hline 1 & Yogyakarta & State Junior High School (SMPN) 9 Yogyakarta \\
& & Nurul Ummah Islamic Junior High School (MTs) Kotagede \\
\hline
\end{tabular}

The data collection was carried out online with respondents, consisting of school principals, teachers, and students. After the online data were collected, offline verification to the respondents was conducted. The number of online and offline respondents is shown in Table 2.

Table 2. Number of Respondents

\begin{tabular}{clcc}
\hline \multirow{2}{*}{ No } & \multicolumn{2}{c}{ Respondents of the Research } & \multicolumn{2}{c}{ Total Number } \\
\cline { 3 - 4 } & School Principal & 2 & Offline \\
\hline 1 & Natural Science Teacher & 5 & 1 \\
2 & Grade X, XI dan XII students & 267 & 2 \\
Total & $\mathbf{2 7 4}$ & - \\
\hline
\end{tabular}

The data collection techniques used were interviews and questionnaires. The instruments used to collect data about online learning systems during the pandemic were interview sheets and questionnaires. The questionnaire was used to collect the data needed to answer all research questions. The instrument validity was validated through expert judgment, then proven through construct validity and reliability. The interview guideline was used to reveal the recognition of the learning system that occurs when the Natural Science subject was being given. In detail, the types of data required and the data collection techniques used are shown in Table 3.

Table 3. Required Data and Instruments Used

\begin{tabular}{cccc}
\hline No & Aspect & Required Data & Instruments Used \\
\hline 1 & Context & Online program objectives & Interview Guideline \\
& & Teacher's professionalism & Interview Guideline \\
2 & Input & The sources of online program readiness & Questionnaires and Documentation \\
& & Natural Science lesson plan & Questionnaires and Interview Guideline \\
3 & Process & Learning implementation activities & Questionnaires and Interview Guideline \\
4 & Product & Natural Science learning outcomes & Questionnaires and Interview Guideline \\
\hline
\end{tabular}

The data collection was carried out in two ways, namely online and offline. Online data collection was carried out by distributing the questionnaire instrument distributed via WhatsApp through the link provided in the form of an online form. Furthermore, offline data collection was conducted by visiting the sample schools listed in Table 1, filling in, and sending the instruments online. In addition, the visit also aims to verify the data that have been sent online and extract the data more deeply.

The data analysis technique used in this research was descriptive qualitative. The results of the evaluation analysis were described and displayed in the form of a percentage table used to determine students' perceptions regarding the online learning system in Natural Science subject. The percentage calculation value $(\%)$ was then converted into a qualitative form to determine the actualization of achievement according to the success criteria.

\section{FINDINGS AND DISCUSSION}

The results of the evaluation begin with the description of the characteristics of the result data and the evaluation discussion is then presented sequentially according to the CIPP model used in the evaluation of online learning systems in Natural Science subject for junior high school as follows. 


\section{Context Evaluation}

According to Estriegana et al. (2019), technological knowledge and e-learning systems have been widely adopted with innovative communication formats and management appropriate to increase students' motivation as the online learning strategy. Based on the analysis results on the context aspect, $57 \%$ of the crucial needs in Natural Science subject cannot be separated from practicum activities which becomes a learning dilemma in managing online planning because the understanding of sustainable practicum activities was not supportive yet in this pandemic. Therefore, it is necessary to have a virtual-based laboratory as a context in online learning programs which makes educational technology a crucial need (Ocran et al., 2020) to mediate the right perspective. It is as stated by Boettcher and Conrad (2016, pp. 54-55) that it can help students to find and identify digitalized sources to achieve more meaningful learning in long-term learning.

Systems that support the needs of the program for beginners and experts in its implementation need to be implanted with meaningful patterns of knowledge related to the implementation of the online learning program. According to Maina et al. (2020), in order to fulfill the need for the online learning program, collaboration and participation are needed. The required learning activities that animate each other through collaboration to build network capacity among other teachers and the elements when teaching and learning activities take place are in the form of pleasure and novelty planting (Tsai \& Tsai, 2020).

\section{Input Evaluation}

On the input aspect, the percentage is $70 \%$ in the good category. The leading indicators indicating online learning readiness are in terms of implementation plans, varied media, assignments and learning loads, and the need for an understanding that leads to the core the Natural Science learning. The learning is carried out through a virtual laboratory for participating students (Firmansyah et al., 2020) as identification of the need to find alternative solutions to determine the quality of support for the online learning program implementation. According to Djaja (2016), the need for professional standards will improve the quality assurance of teaching and learning activities. It is also supported by the statement of McDavid et al. (2013, p. 52) that the resources during the program, especially in the Natural Science subject are very needed. This is emphasized by the statement of Meivawati et al. (2018) that the presence of technology is very important to support the implementation of character and moral education in the 21 st-century education era. It is because technology and character education can motivate students to possess skills such as critical thinking, problem-solving, knowledge application, creativity, flexibility, communication, interpersonal, collaboration, leadership, and global and cross-cultural awareness.

\section{Process Evaluation}

On the process aspect, it gains a score of $67 \%$ in the good category. However, this indicator is not optimal because there is still a need for improvement referring to the essence of Natural Science learning activities that the process is established through practicum activities during this pandemic. A virtual laboratory could be an innovative solution and make it easier to access it. The need for standards to be considered is in accordance with the statement of Bhakti (2017) regarding the standard of the learning process in Government Regulation No. 41 of 2007. It is also correlated with the statement of Thomas et al. (2020) that online learning program is proven to increase transitional resources in providing information and social management during online learning activities. Teaching and learning activities through online learning program are expected to be able to increase critical thinking skills in students. Natural Science subject which cannot be separated from practicum and is assisted by a virtual labora- 
tory can be an alternative (Sari \& Dewi, 2020). According to Boettcher and Conrad (2016, p. 178), through these activities, learning is centered on students and makes it easier for teachers to observe more deeply and focus on the affective and psychomotor domains of the students. Modifications in learning styles are needed to provide new understanding through different or non-monotonous processes so that the knowledge will be more easily absorbed, understood, and maintained (Arshavskiy, 2017, p. 58).

\section{Product Evaluation}

On the product aspect, it reaches a percentage of $69 \%$. According to Kuntarto (2017), it is measured by the success of efforts in achieving targeted needs and accessing planned or unplanned benefits. Therefore, the result is still considered independent tasks. Meanwhile, the response from students which is indicated by the percentage of $69 \%$, is considered in the good category. This result is in the form of independent tasks from teachers to students, that are not considered burdensome to them. Educational life in the 21 st century becomes an opportunity for teachers in online learning. Responding to the changes that require new knowledge, skills, and positions (Trust et al., 2016), the results of product analysis help schools regarding progress, and it becomes the alternatives to overcome the obstacles. According to Kuntarto (2017), the purpose of this evaluation is to establish the process of providing new experiences. Perceptions of students and the development of various solutions through online learning that undergoes intense changes are needed because the results could be technological innovations in learning (Popovici \& Mironov, 2015). Furthermore, according to Harahap (2020), the correlation of creativity as an effort to attract the attention of students in carrying out learning with more focus is in accordance with the mission of remote learning. Data collection was studied in more depth by finding the answers of how the online learning system for Natural Science subject at the junior high school level in certain areas in Yogyakarta within the radius of the school location made it possible to carry out evaluation activities during the pandemic. Given that long-term needs can help the learning to be more meaningful in achieving structured knowledge (Boettcher \& Conrad, 2016, p. 59).

A good instrument will measure what will be measured according to the dimensions used. The implementation that needs to be considered is the instrument construction principles, namely the validity and reliability of the instrument. The calculation of reliability on the evaluation instrument in this research was estimated using the Cronbach Alpha coefficient. The reliability coefficient that was analyzed was the reliability coefficient $\alpha$ of 0.782 . The validity value is used to simplify and explain the relationship between components in the form of factors (Firdaos, 2016). The analysis is needed to determine the number of factors or dimensions being measured which is obtained through the analysis of Exploratory Factor Analysis (EFA) (Mardapi, 2008).

Factor or component analysis, which was conducted by identifying the structure and showing how much the number of variables, can explain every aspect of the CIPP evaluation model used. However, data reduction was still needed to be done (Akhmad et al., 2016). The value of the KMO and Bartlett's test reaches 0.721. This is greater than 0.50 and Bartlett's Test of Sphericity (sig) value reaches 0.000 . This value is less than 0.05 , which means that this value indicates effectiveness in the use and can be continued for factor analysis. According to Hernikawati and Sensuse (2016), the next step is to analyze the correlation between the instrument items. In the anti-image column, it can be seen that the correlation value of items is as follows: $1=0.737$, item $2=0.744$, item $3=0.706$, item $4=0.730$, item $5=0.716$, item $6=$ 0.672 , item $7=0.799$, item $8=0.766$, item $9=0.846$, item $10=0.839$, item $11=0.780$, item $12=0.842$, item $13=0.623$, item $14=0.831$, item $15=0.753$, item $16=0.712$, item $17=$ 0.634 , item $18=0.762$, item $19=0.624$ and item $20=0.621$. Since all correlation values from each item, in general, have the Measure of Sampling Adequacy (MSA) value. Then, the values have 
to be interpreted according to the MSA principle. If the value of MSA>0.05, then the variables can still be predicted and can be analyzed further (Prasetyo et al., 2019). However, If the value of $M S A<0.5$, then the variable cannot be predicted and cannot be further analyzed, or it should be excluded from other variables. The results of the MSA recapitulation value reached the value above 0.05 . Therefore, it can be said that all variables are feasible for further analysis (Firdaos, 2016). From these results, MSA values for all variables are known. In the Exploratory Factor Analysis (EFA) in this research, there are 4 factors that are formed and can represent the number of indicators. The number of factors formed must first consider the eigenvalue. A factor is said to be formed if the value of eigenvalue is $>1$. The value of eigenvalue is always sorted from the largest to the smallest value (Sitinjak et al., 2017). Then, 20 items have been reduced. The component of factor 1 is able to explain $21.46 \%$ variants, and reduced to factor 2 which can explain $32.5 \%$, and reduced to factor 3 which can explain $39.42 \%$, and reduced to factor 4 which can explain $45.72 \%$. Factor analysis can be continued because the instrument items are able to explain $139.1 \%$. Thus, factor analysis can be continued because the value of Total Variance Explained has met the condition, which is $>60 \%$ (Akhmad et al., 2016). Overall, the Total Variance Explained can be depicted in Figure 1.

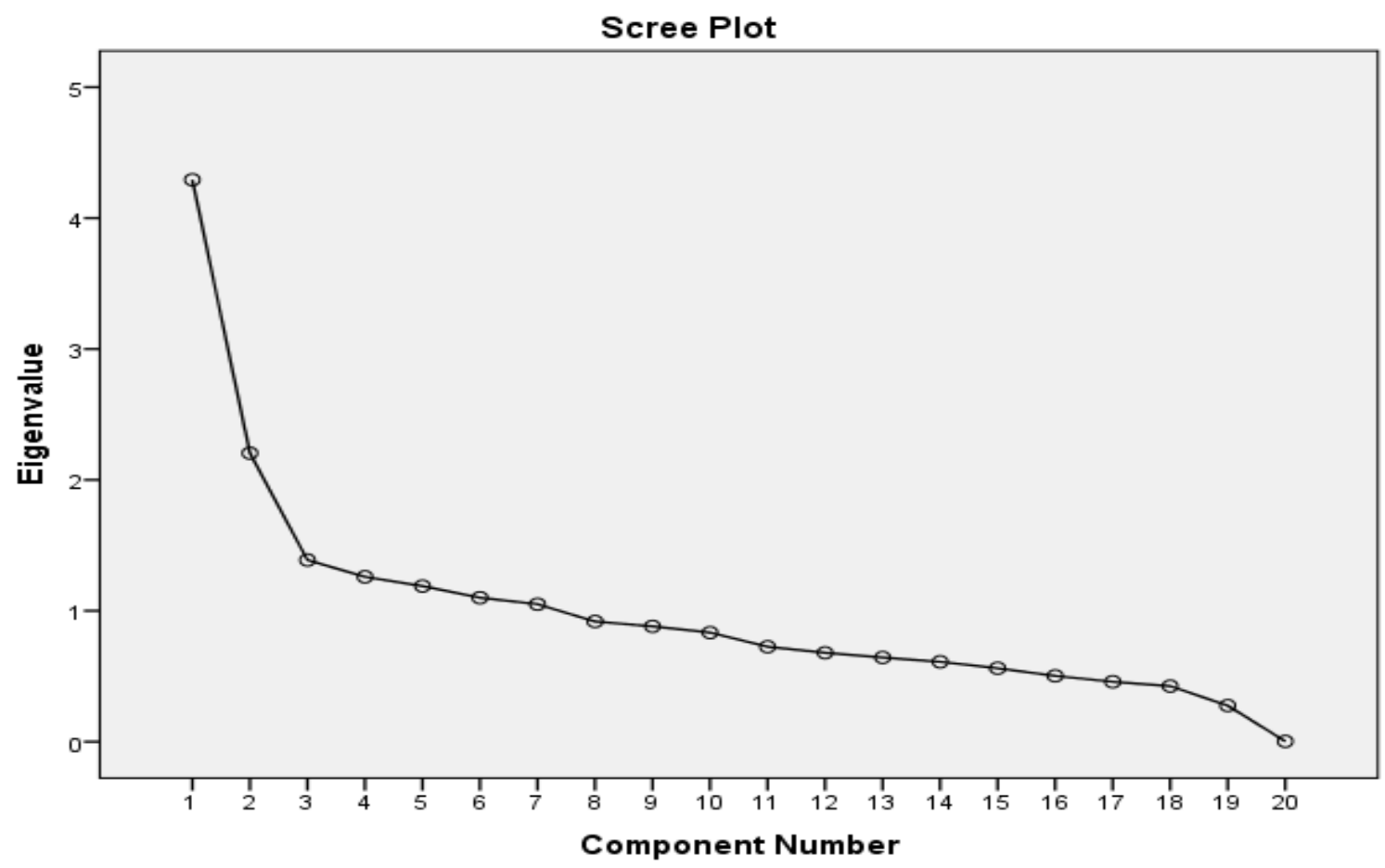

Figure 1. Scree Plot

If Total Variance Explained explains the number of factors formed by calculating the values, then the Scree Plot displays the values in the form of a graph. The result of the output scree plot in Figure 1 shows the data point that is above the break (the inflection point) that changes the $\mathrm{X}$-axis component value from 1 to 4 with the direction of the line that decreases sharply. Then, starting from values 4, 5, 6, and so on, it can be seen that the line starts to slope and all analysis factors after point 4 are below the number one on the eigenvalue Y-axis. This shows that the 4 factors that are formed are best for summarizing 20 items of online learning instruments for Natural Science subject. In this research, the variables of 20 items that have been extracted with factor loadings of $\leq 0.05$ are considered to have a weak contribution to the factors formed so they must be reduced from the factors they form (Verdian, 2019). The components formed are presented in Table 4. 
Table 4. Rotated Component Matrix

\begin{tabular}{|c|c|c|c|c|}
\hline & \multicolumn{4}{|c|}{ Component } \\
\hline & 1 & 2 & 3 & 4 \\
\hline C1 & & & & .622 \\
\hline C2 & & & & .521 \\
\hline C3 & & & .462 & .614 \\
\hline C4 & & & & \\
\hline C5 & & & .434 & .656 \\
\hline I1 & & .437 & & \\
\hline I2 & & & .524 & \\
\hline I3 & & & .599 & \\
\hline I4 & .669 & & & \\
\hline I5 & .415 & & & \\
\hline P1 & & .624 & & \\
\hline P2 & & & .610 & \\
\hline P3 & & & -.484 & \\
\hline P4 & .409 & & .465 & \\
\hline P5 & & .732 & & \\
\hline PR1 & & .467 & .518 & \\
\hline PR2 & & & & \\
\hline PR3 & & .695 & & \\
\hline PR4 & .852 & & & \\
\hline PR5 & .854 & & & \\
\hline
\end{tabular}

Based on Table 4, the items of factor 1 consist of item number 9, 10, 14, 19, and 20. On factor 2, the items consist of $6,11,15,16$, and 18. On factor 3 , the items consist of 3, 5, 7, 8, 11,13 , and 16, while, on factor 4 , the items consist of $1,2,3$, and 5 . Thus, the twenty instrument items that have been reduced are formed and divided into four factors indicating adequate criteria and meet the minimum standards specified in each test. The suitability of the required data is then reduced to several indicators of evaluation aspects. The indicators are shown in Table 5.

Table 5 shows the indicators used to capture and obtain the required information. The results of data analysis from the percentage of online learning programs for Natural Science subject are presented in Table 6.

Table 5. Indicators of Natural Science Online Learning

\begin{tabular}{cl}
\hline Aspect & \multicolumn{1}{c}{ Indicator } \\
\hline Context & The flexibility and operation are in the form of internet connection, digitization, and other devices \\
& Teacher professionalism strategy supports the practicum activities \\
& The implementation of the curriculum is in accordance with the Natural Science subject \\
The suitability of the aspect of achieving the objectives of Natural Science learning \\
Input & The existence of facilities and infrastructures in the form of internet network access \\
& Eligibility of online system procedures conducted by the schools \\
& The existence of scheduling and the cost of implementing online learning \\
The ability of the teachers to conduct Natural Science online learning & \\
Process & Complete learning tools \\
Product & The implementation of practicum activities \\
& The quality of results of learning activities seen from cognitive, affective, and psychomotor aspects \\
& The effectiveness of implementing online learning
\end{tabular}

Table 6. Evaluation Results

\begin{tabular}{ccc}
\hline Aspect & Results in Percentage & Category \\
\hline Context & $57 \%$ & Fairly Good \\
Input & $70 \%$ & Good \\
process & $67 \%$ & Good \\
Product & $69 \%$ & Good \\
\hline
\end{tabular}


Table 6 shows the percentage of achievements of online learning system implementation in Natural Science for junior high school based on student responses from the five aspects evaluated. The responses that are obtained online indicate the participation of grade X, XI, and XII students in filling out the online questionnaire form according to Sugiyono (2017), with the samples which are in accordance with the quota met. The objectives of the online learning system in Natural Science subject according to technical and implementation guidelines consist of several things, namely the schools are able to meet flexibility needs, ideal operational technology tools, professionalism strategies in practicum activities, support in the form of facilities and infrastructure, scheduling and procedures and the capabilities of teachers during online learning in schools, the completeness and implementation of online learning, the quality of learning outcomes and the effectiveness of the online learning system implementation support. The implementation of online learning in Natural Science subject has received appreciation from many parties, especially school principals, teachers, and students, aiming to maintain the implementation of teaching and learning activities. It is in line with the statement of Ashavskiy (2017, p. 23) that the learning will be more effective and a better understanding factor will be met when combined with technological advances.

\section{CONCLUSION}

The results of the evaluation of online learning programs in Natural Science subject using the Context, Input, Process, Product (CIPP) evaluation model, through the instruments used show the results of validity and reliability, show adequate criteria, as well as meet the minimum standards and reliability in good the category. Based on the results of the evaluation, it can be concluded that the context aspect has met the needs of flexibility, ideal operational technology tools, and professionalism of teachers in practicum activities which are considered in the fairly good category. Based on the input aspect, the online application system, support in the form of internet access infrastructure, scheduling, and procedures, and the capabilities of teachers are considered in the good category. According to the process aspect, the implementation of online learning is considered in the good category. While, according to the product aspect, the quality achievement of learning outcomes and online learning systems implementation support are considered in the good category. Referring to Boettcher and Conrad (2016, p. 220), evaluation activities related to online learning with the Synchronous strategy are able to support and build social values during the teaching and learning activities aiming to achieve learning outcomes.

\section{REFERENCES}

Akhmad, A. L., Mujianto, J., \& Elmubarok, Z. (2016). Pengembangan instrumen penilaian psikomotorik siswa materi speaking di SMA Semesta Gunung Pati Kota Semarang. Journal of Educational Research and Evaluation, 5(1), 41-48. Retrieved from https://journal. unnes.ac.id/sju/index.php/jere/article/view/14882

Arshavskiy, M. (2017). Instructional design for eLearning: Essential guide to creating successful eLearning courses. Your Elearning World.

Bhakti, Y. B. (2017). Evaluasi program model CIPP pada proses pembelajaran IPA. Jurnal Inovasi Pendidikan Fisika Dan Riset Ilmiah, 1(2), 75-82. https://doi.org/10.30599/jipfri. v1i2.109

Boettcher, J. V., \& Conrad, R. M. (2016) The online teaching survival guide: Simple and practical pedagogical. Jossey-Bass.

Djaja, S. (2016). Harapan dan tantangan guru pembelajar moda daring. Jurnal Pendidikan Ekonomi, 10(2), 1-12. 
Estriegana, R., Medina-Merodio, J. A., \& Barchino, R. (2019). Student acceptance of virtual laboratory and practical work: An extension of the technology acceptance model. Computers and Education, 135, 1-14. http://doi.org/10.1016/j.compedu.2019.02.010

Firdaos, R. (2016). Aplikasi analisis faktor konfirmatori terhadap sikap keberagamaan mahasiswa. Jurnal Penelitian Sosial Keagamaan, 10(2), 359-380. https://doi.org/10.18326/ infsl3. v10i2.359-380

Firmansyah, F., Rahayu, W., \& Nurjannah, N. (2020). Evaluation of the entrepreneurship education program through extracurricular activities of Student Company. Jurnal Penelitian Dan Evaluasi Pendidikan, 24(1), 51-61. https://doi.org/10.21831/pep.v24i1. 19783

Harahap, S. (2020). Identifikasi kreativitas siswa terhadap mata pelajaran IPA. Integrated Science Education Journal, 1(1), 16-22. https://doi.org/ 10.37251/isej. v1i1.21

Hasbullah, M. (2015). Kebijakan pendidikan dalam perspektif teori, aplikasi dan kondisi objektif. Raja Grafindo Persada.

Hernikawati, D., \& Sensuse, D. I. (2016). Uji validitas indikator-indikator peme ringkatan egovernment Indonesia (PeGi) tingkat provinsi dengan analisis faktor. Jurnal Penelitian Pos dan Informatika, 6(1), 1-18. https://doi.org/10.17933/jppi.2016.060101

Islam, S. M. D. U., Bodrud-Doza, M., Khan, R. M., Haque, M. A., \& Mamun, M. A. (2020). Exploring COVID-19 stress and its factors in Bangladesh: A perception-based study. Heliyon, 6(7), 1-10. https://doi.org/10.1016/j.heliyon.2020.e04399

Khamidah, N., Winarto, W., \& Mustikasari, V. R. (2019). Discovery learning: Penerapan dalam pembelajaran IPA berbantuan bahan ajar digital interaktif untuk meningkatkan prestasi belajar siswa. JIPVA (Jurnal Pendidikan IPA Veteran), 3(1), 87-99. https://doi.org/ $10.31331 /$ jipva.v3i1.770

Kuntarto, E. (2017). Keefektifan model pembelajaran daring dalam perkuliahan bahasa Indonesia di perguruan tinggi. Journal Indonesian Language Education and Literature, 3(1), 53-65. Retrieved from https://www.syekhnurjati.ac.id/jurnal/index.php/jeill/article/ view/1820

Maina, M. F., Santos-Hermosa, G., Mancini, F., \& Ortiz, L. G. (2020). Open educational practices (OEP) in the design of digital competence assessment. Distance Education, 41(2), 261-278. https://doi.org/10.1080/01587919.2020.1757407

Mardapi, D. (2008). Teknik penyusunan instrumen (tes dan nontes). Mitra Cendekia.

McDavid, J. C., Huse, I., \& Ingleson, L. R. L. (2013). Program evaluation and performance measurement: An introduction to practice. SAGE.

Meivawati, E., Kartowagiran, B., \& Rustini, T. (2018). Evaluation of character and moral education in elementary school. The Online Journal of New Horizons in Education, 8(4), 6372. Retrieved from http://www.tojned.net/journals/tojned/articles/v08i04/v08i0406.pdf

Ocran, T. K., Underwood, E. P. G., \& Arthur, P. A. (2020). Strategies for successful implementation of mobile phone library services. Journal of Academic Librarianship, 46(5). https://doi.org/ 10.22219/jpbi.v6i2.11953

OECD. (2016). Innovating education and educating for innovation: The power of digital technologies and skills. OECD. 
Popovici, A., \& Mironov, C. (2015). Students' perception on using e-learning technologies. Procedia - Social and Behavioral Sciences, 180, 1514-1519. https://doi.org/10.1016/j.sbspro. 2015.02.300

Prasetyo, K., Masrukan, M., \& Sunawan, S. (2019). Development of mathematical literation instruments based on class IV geometry material conservation. Journal of Educational Research and Evaluation, 8(1), 1-13. https://doi.org/ 10.15294/jere.v8i1.28261

Sari, D. R., Tangkudung, J., \& Hanif, A. S. (2018). Evaluasi program pemusatan latihan daerah (Pelatda) Bolavoli Pasir Putri DKI Jakarta. Jurnal Ilmiah Sport Coaching and Education, 2(1), 8-16. https://doi.org/10.21009/JSCE.02102

Sari, N., \& Dewi, U. P. (2020). Analisis sikap terhadap penyelidikan IPA, kesenangan dalam IPA dan ketertarikan berkarir bidang IPA di SMPN 3 Batanghari. Jurnal Dimensi Pendidikan Dan Pembelajaran, 8(2), 72-80. http://dx.doi.org/10.24269/dpp.v8i2.1848

Siswadi, Y., Houghty, G. S., \& Agustina, T. (2019). Implementation of the CIPP evaluation model in Indonesian nursing schools. Jurnal Ners, 14(3), 126-131. http://dx.doi.org/ 10.20473/jn.v14i3(si)

Sitinjak, D. A., Suryawardani, I. G. A. O., \& Wijayanti, P. U. (2017). Analisis faktor-faktor yang menentukan kepuasan kerja dan loyalitas karyawan. E-Jurnal Agribisnis Dan Agrowisata, 6(3), 378-386. https://doi.org/10.24843/JAA.2017.v06.i03.p06

Sugiyono, S. (2017). Metode penelitian pendidikan (pendekaan kuantitatif, kualitatif dan R\&D). Alfabeta.

Thomas, L., Orme, E., \& Kerrigan, F. (2020). Student loneliness: The role of social media through life transitions. Computers and Education, 146, 103754. https://doi.org/10.1016/ j.compedu.2019.103754

Trust, T., Krutka, D. G., \& Carpenter, J. P. (2016). “Together we are better": Professional learning networks for teachers. Computers and Education, 102, 15-34. https://doi.org/ 10.1016/j.compedu.2016.06.007

Tsai, Y. L., \& Tsai, C. C. (2020). A meta-analysis of research on digital game-based science learning. Journal of Computer Assisted Learning, 36(3), 280-294. https://doi.org/10.1111/ jcal.12430

Ulmunir, M. (2018). Perencanaan pendidikan. Universitas Islam Negeri Sunan Kalijaga.

Verdian, E. (2019). Analisis faktor yang merupakan intensi perpindahan merek transportasi online di Surabaya. Jurnal AGORA, 7(1). Retrieved from http://publication.petra.ac.id/ index.php/manajemen-bisnis/article/view/8176

Wirawan, W. (2016). Evaluasi (teori, metode, metodologi, standar, aplikasi dan profesi). Rajawali Press.

Wisudawati, A. W. (2013). Metodologi pembelajaran IPA . Bumi Aksara. 